\title{
Påvisning av spinalvæskelekkasje med farget klorheksidin
}
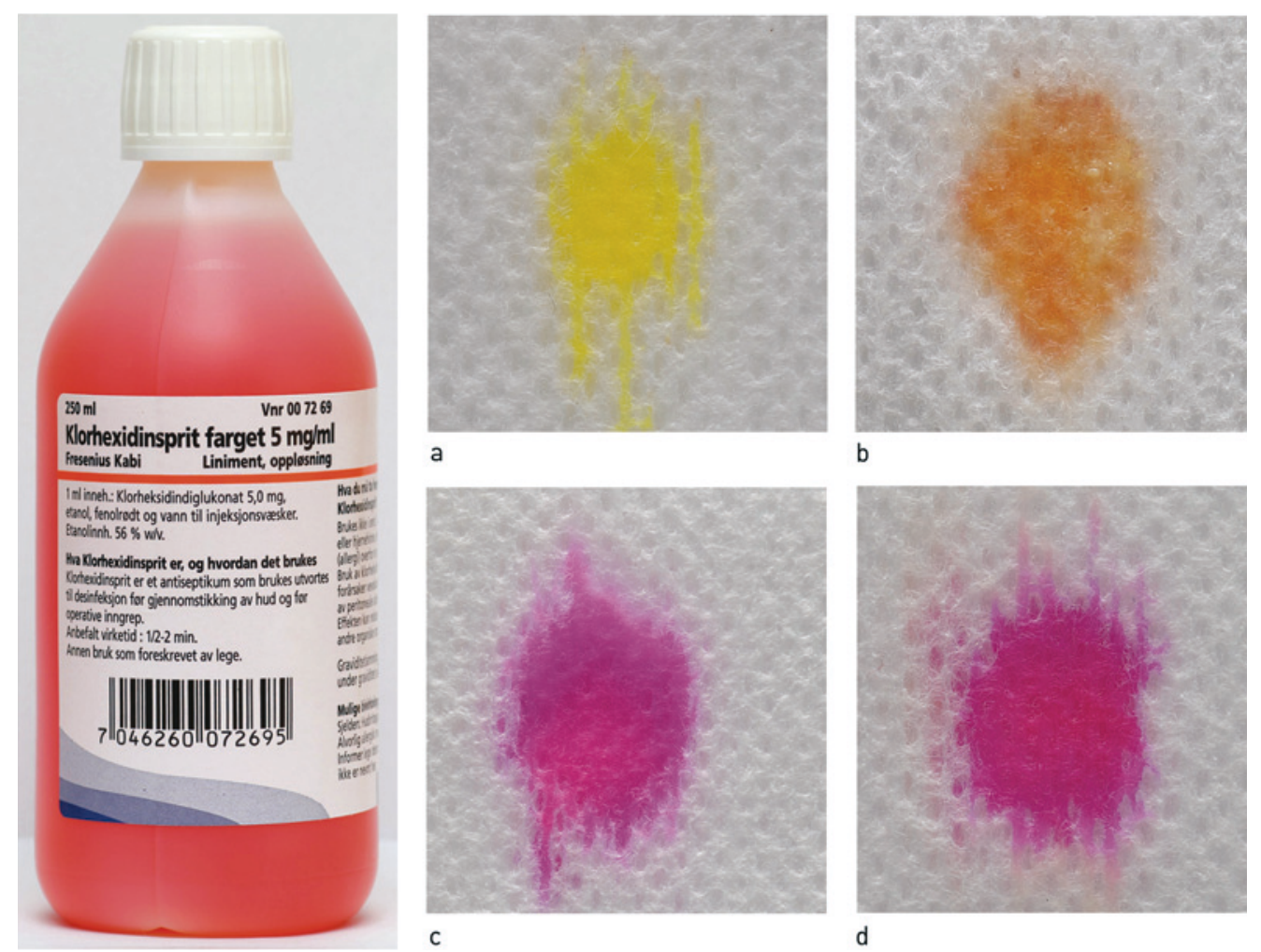

d

Rask og enkel påvisning av spinalvæskelekkasje ved hodeskader er viktig for diagnostikk og tidlig oppstart av korrekt behandling. Oss bekjent eksisterer det ingen gode hurtigdiagnostiske tester for påvisning av spinalvæske. Måling av sukkerkonsentrasjon og proteininnhold gir oftest usikre resultater. Ved Universitetssykehuset Nord-Norge i Tromsø har man i en årrekke brukt farget klorheksidin til påvisning av spinalvæske med godt resultat. Teknikken er svært enkel og billig, og vi synes den fortjener å bli bedre kjent $i$ det medisinske miljø.

Spinalvæske som har vært i kontakt med luft, har en $\mathrm{pH}$-verdi på 7,8-8,1. Den skiller seg fra blod, slim og spytt som har lavere $\mathrm{pH}$, typisk 7,2-7,48 (1). Farget klorheksidin til desinfisering av hud finnes på alle sykehus og legekontorer. Den svake gulfargen skriver seg fra fenolrødt som produsenten har tilsatt den vannklare klorheksidinløsningen, antakelig for lettere å se hvilke deler av huden som er desinfisert. Fenolrødt er imidlertid også en pH-indikator. Den får et intenst lilla fargeomslag ved $\mathrm{pH}$-verdi rundt 8 . Svakt alkaliske væsker, eksempelvis spytt, gir et svært ulikt fargeomslag i retning brunrødt.
Spinalvæskelekkasje fra nese eller øre ved hodeskader er ofte blodtilblandet, men mengden av blod er oftest beskjeden. En tilsetning av blod til spinalvæske i konsentrasjon $1 \mathrm{~g}$ hemoglobin/100 ml løsning gir fremdeles et svært tydelig rødlilla indikatoromslag.

På bildet ses farget klorheksidinløsning på et kompress (A), og fargeomslag etter tilsetning av spytt (B), spinalvæske (C) og $1 \%$ blodtilblandet spinalvæske (D).

Takk til Rune Hennig for særdeles god veiledning.

\section{Inger Marie Waal Nilsbakken}

Linnea Berg Karlsen

bergkarlsen@hotmail.com

Universitetet i Troms $\varnothing$ - Norges arktiske universitet

\section{Raymond Jakobsen}

Laboratoriemedisin

Universitetssykehuset Nord-Norge

Inger Marie Waal Nilsbakken (f. 1993) er medisinstudent.

Forfatter har fylt ut ICMJE-skjemaet og oppgir ingen interessekonflikter.
Linnea Berg Karlsen (f. 1994) er medisinstudent.

Forfatter har fylt ut ICMJE-skjemaet og oppgir ingen interessekonflikter.

Raymond Jakobsen (f. 1976) er spesialbioingeniør.

Forfatter har fylt ut ICMJE-skjemaet og oppgir ingen interessekonflikter.

Litteratur

1. Cunniffe JG, Whitby-Strevens S, Wilcox MH. Effect of $\mathrm{pH}$ changes in cerebrospinal fluid specimens on bacterial survival and antigen test results. J Clin Pathol 1996; 49: 249-53.

Mottatt 20.5. 2014, første revisjon innsendt 27.8. 2014, godkjent 6.10. 2014. Redaktør: Hanne Støre Valeur.

Engelsk oversettelse på www.tidsskriftet.no 